\title{
A new species of Heterochondria (Copepoda: Chondracanthidae) parasitic on many-banded sole, Zebrias fasciatus (Pleuronectiformes: Soleidae) from Korea, with a key to the species of the genus
}

\author{
Seong Yong Moon ${ }^{1,2}$ and Ho Young Soh ${ }^{2}$ \\ ${ }^{1}$ Department of Biology, Gangneung-Wonju National University, Gangneung, Korea; \\ ${ }^{2}$ Division of Marine Technology, Chonnam National University, Yeosu, Korea
}

\begin{abstract}
A new species of Chondracanthidae (Copepoda: Cyclopoida), Heterochondria orientalis sp. n., is described based on specimens of both sexes collected from the gill rakers and the inner side of the operculum of the many-banded sole, Zebrias fasciatus (Basilewsky), from the Yellow Sea, Korea. The new species resembles most closely H. zebriae (Ho, Kim et Kuman, 2000), but can be distinguished from this species and other congeners by the shape of the trunk and length of the antenna, the number of teeth on the mandible and the terminal process of the maxilla, and the structure of the male antennule and maxilliped. Heterochondria orientalis is the first copepod species reported from Z. fasciatus and the first heterochondrid species reported from sole fishes in the Northwest Pacific. A key to distinguish all 10 nominal species of the genus is provided.
\end{abstract}

Keywords: fish parasite, taxonomy, sole fish, parasitic copepod, Korea

Copepods of the family Chondracanthidae Milne Edwards, 1840 are ectoparasites of marine fishes (Ho et al. 2000) and about 180 species of 49 genera have been described (Østergaard 2003, Braicovich and Timi 2009, Alarcos and Timi 2011, Cantatore et al. 2011, Ho et al. 2011, Uyeno and Nagasawa 2012). Three genera, namely Acanthochondria Oakley, 1930, Chondracanthus Delaroche, 1811 and Heterochondria Yü, 1935, include 120 nominal species (Ho et al. 2000, 2011, Boxshall and Halsey 2004). Although flatfishes are the most preferred hosts of chondracanthids (Ho 1982, Ho et al. 2000, 2011), only one species have so far been reported from these fishes in Korea (Kim 1998). Currently, 52 species of chondracanthid copepods have been found in Korean waters (Kim et al. 2005).

During a parasitological survey in Korea, we collected copepods of the genus Heterochondria from the manybanded sole Zebrias fasciatus (Basilewsky). This species, which is considered as new to science, is described in the present paper. In addition, a key is provided for all 10 nominal species of Heterochondria.

\section{MATERIALS AND METHODS}

A total of 12 specimens of the many-banded sole, Zebrias fasciatus, were obtained from the trawlers fishing in the Yellow Sea, Korea. Individual fish were packed in separate plastic bags.
In the laboratory, the parasites were removed from the gill rakers, fixed in 5\% formaldehyde and stored in $70 \%$ ethanol. For microscopic examination of the parasites, the preserved copepod specimens were soaked in lactic acid for a minimum of $24 \mathrm{~h}$ prior to examination using an Olympus SZ30 compound microscope and mounted on slides in lactophenol and sealed with nail vernish. Dissection was done using the reversed slide method (Humes and Gooding 1964).

All drawings were made using the microscope Olympus BX51 equipped with a drawing tube. Total body length of individuals was measured using an image analysis system (Image Pro Plus, version 5.1 for Windows, Media Cybernetics, Silver Spring, Maryland). All measurements are in micrometres unless otherwise indicated. Morphological terminology follows Boxshall and Halsey (2004) and fish names conform to FishBase (Froese and Pauly 2012). Type specimens are deposited at the National Institute of Biological Resources (NIBR), Incheon, Korea.

\section{RESULTS}

Heterochondria orientalis $\mathrm{sp} . \mathrm{n}$.

Figs. 1-25

Female (based on paratypes) (Figs. 1-17): Body 2.61$3.17 \mathrm{~mm}$ long excluding inflated antennules, bottle-like shape dorsally and inflated laterally (Figs. 1-3). Head 1.26 times $(645 \times 510)$ longer than wide, with rounded knob at each anterolateral corner and ventrally protruded at oral region; M-shaped chitinous frame on dorsal margin (Figs. 1, 2). First pediger narrower than head. Sec- 


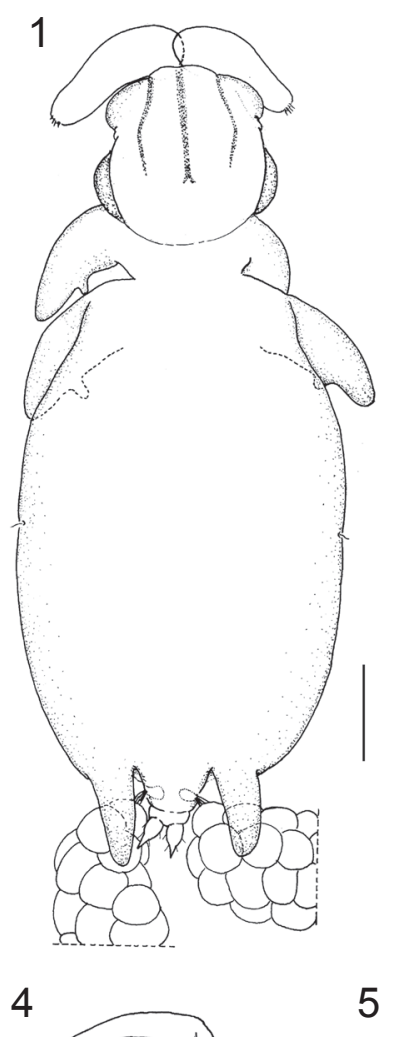

4

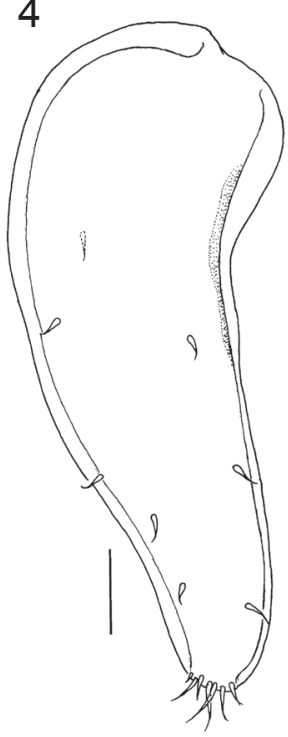

2
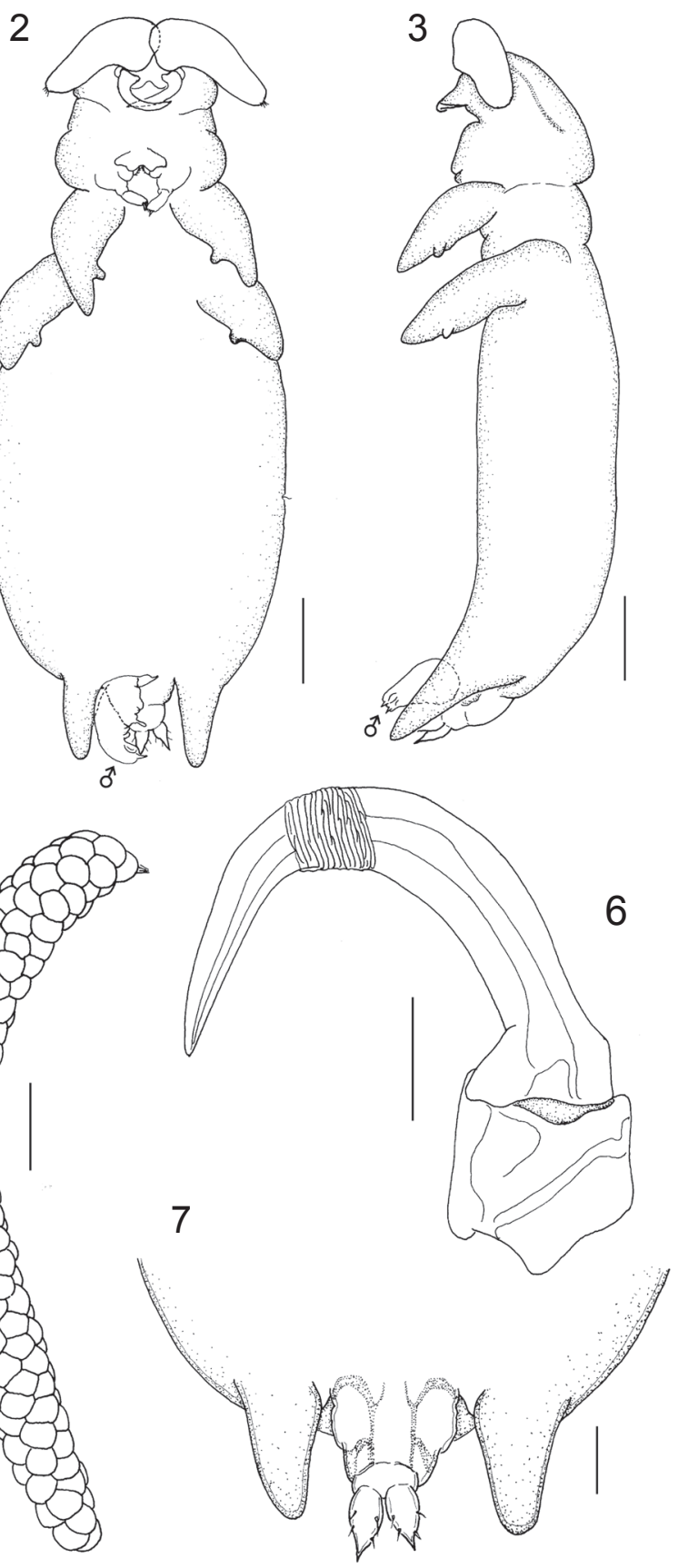

Figs. 1-7. Heterochondria orientalis sp. n., ovigerous female. Fig. 1. Habitus, dorsal view. Fig. 2. Habitus, ventral view. Fig. 3. Habitus, lateral view. Note male $\left({ }^{3}\right)$ illustrated on Figs. 2 and 3. Fig. 4. Antennule, dorsal view. Fig. 5. Egg sac. Fig. 6. Antenna, dorsal view. Fig. 7. Posterior part of trunk, ventral view. Scales bars: Figs. 1-3, 5=300 $\mu$ m; Figs. 4, $6=50 \mu \mathrm{m}$; Fig. $7=100 \mu \mathrm{m}$.

ond pediger with remaining prosomal somites fused into a long, cylindrical trunk bearing pair of posterolateral processes (Fig. 7). Genital double somite (Fig. 7) $126 \times$ 208 , i.e. $1.65 \times$ wider than long; abdomen $75 \times 108$, i.e. $1.44 \times$ wider than long. Caudal ramus (Fig. 7) spiniform, pointed process bearing four setae each. Longest egg sac (Fig. 5) $3.81 \mathrm{~mm}$ long, nearly 1.4 times as long as body length.

Antennule (Fig. 4) fleshy and inflated, armature being (from proximal to distal) 1, 2, 3, 2, 7. Antenna (Fig. 6) two-segmented; terminal segment sharply curved claw with striation in subterminal region. Labrum (Fig. 10) with W-shaped posterior margin. Mandible (Fig. 11) twosegmented; terminal blade with 34-36 teeth on convex (inner) side and 24-26 on concave (outer) side. Paragnath (Fig. 12), small, spinulose lobe. Maxillule (Fig. 13) with two terminal elements. Maxilla (Fig. 17) two-segmented; first segment robust, unarmed; second segment bearing small, simple, basal seta, one large seta with hyaline tip and terminal blade with 16 teeth on convex side and 

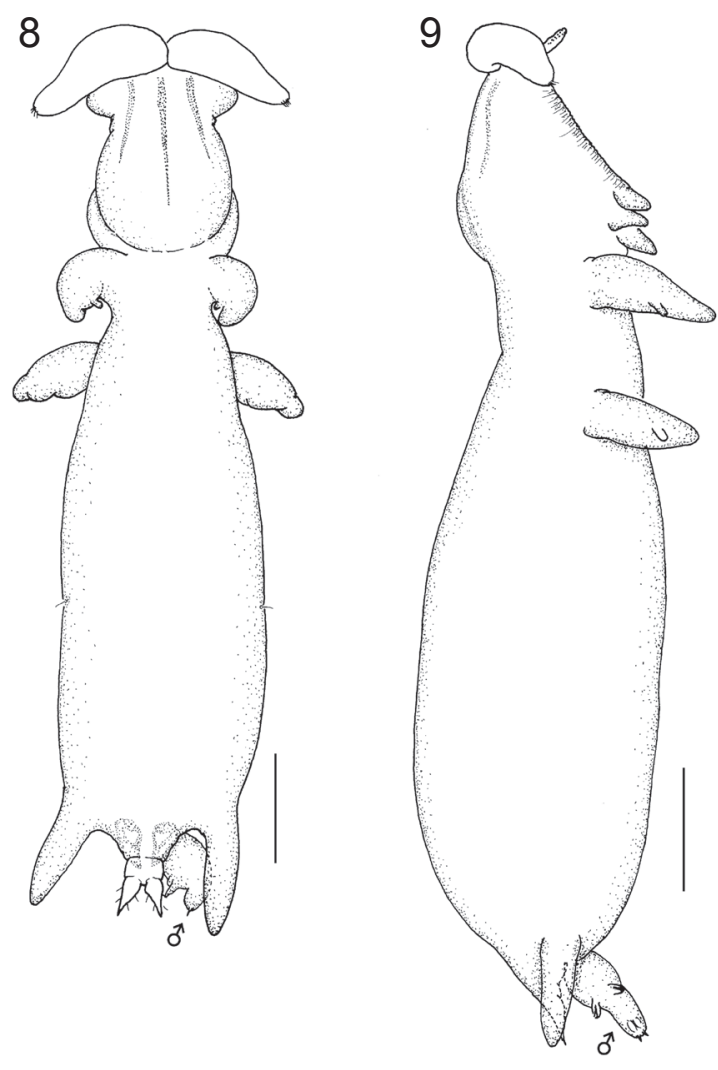

10

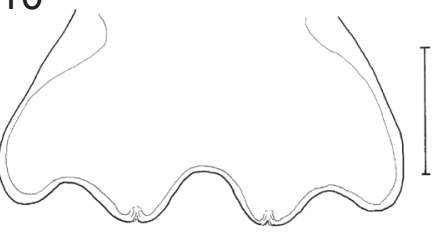

11

12
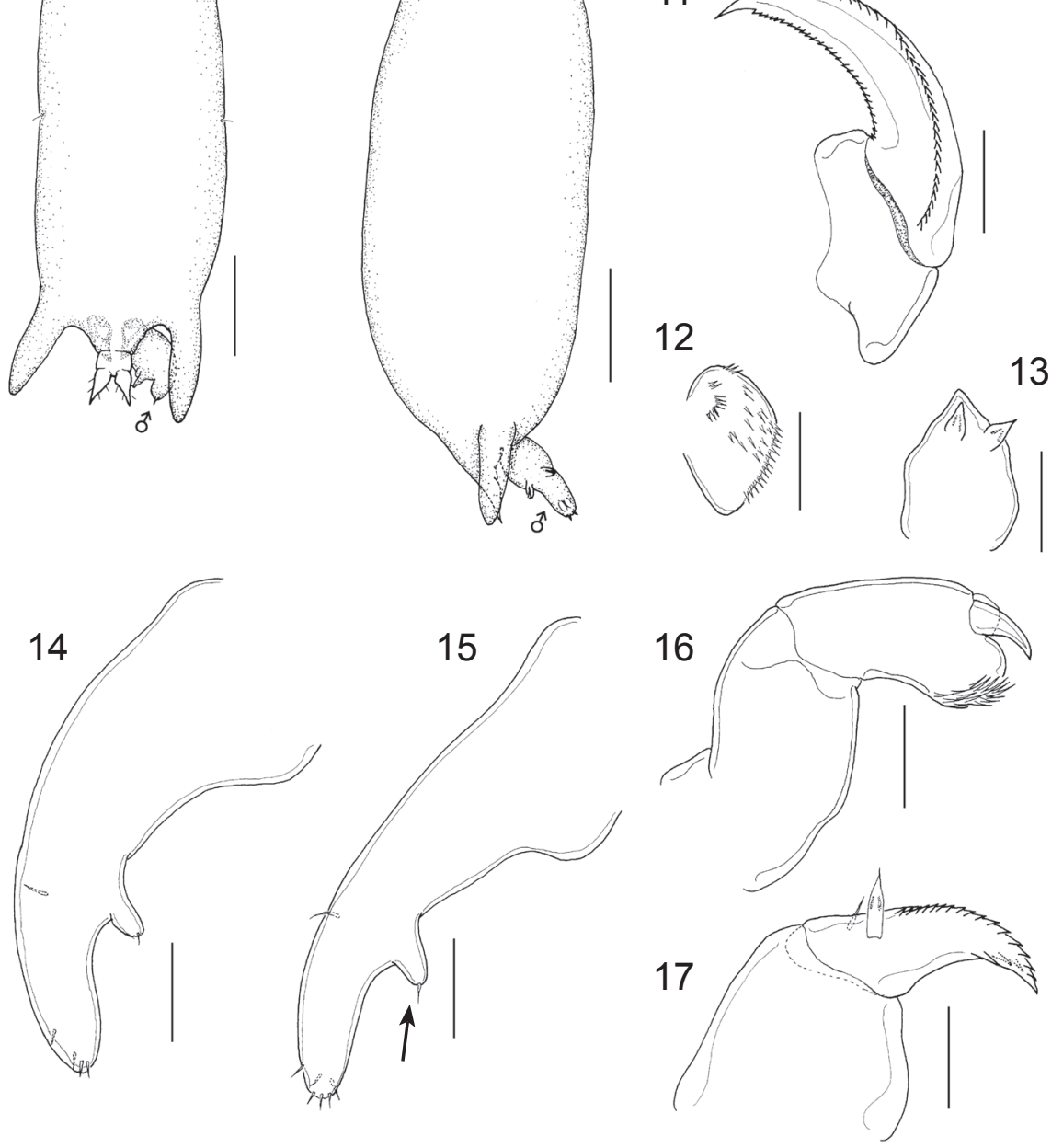

Figs. 8-17. Heterochondria orientalis sp. n., ovigerous female. Fig. 8. Non-ovigerous female, dorsal view. Fig. 9. Non-ovigerous female, lateral view. Note male $\left({ }^{\Uparrow}\right)$ illustrated on Figs. 8 and 9. Fig. 10. Labrum. Fig. 11. Mandible. Fig. 12. Paragnath, dorsal view. Fig. 13. Maxillule. Fig. 14. Leg 2. Fig. 15. Leg 1 (arrow indicates nipple-like bud). Fig. 16. Maxilliped. Fig. 17. Maxilla. Scales bars: Figs. $8,9=300 \mu \mathrm{m}$; Figs. 14, $15=50 \mu \mathrm{m}$; Figs. 10-13, 16, $17=20 \mu \mathrm{m}$.

three teeth on concave side. Maxilliped (Fig. 16) threesegmented; first segment largest, unarmed; second segment with long spines on greatly protruded inner distal corner; terminal segment reduced to small hook situated opposite to tuft of spinules on inner-distal corner of second segment. Both legs 1 (Fig. 15) and 2 (Fig. 14) nearly unilobate, with inflated, bluntly pointed exopod continued with protopod and carrying much reduced endopod tipped with single seta. Terminal region of exopod with six setae on leg 1 and four setae on leg 2 .

Male (Figs. 18-25): Body (Figs. 18, 19) 375 long, with swollen cephalosome and cylindrical metasome and urosome. Genital somite usually with venterolateral ridges. Abdomen (Fig. 19) indistinguishably fused with genital segment. Caudal ramus as in female, but naked. Antennule absent. Antenna (Fig. 21) two-segmented with small seta on basal segment; terminal segment with a stout claw. 

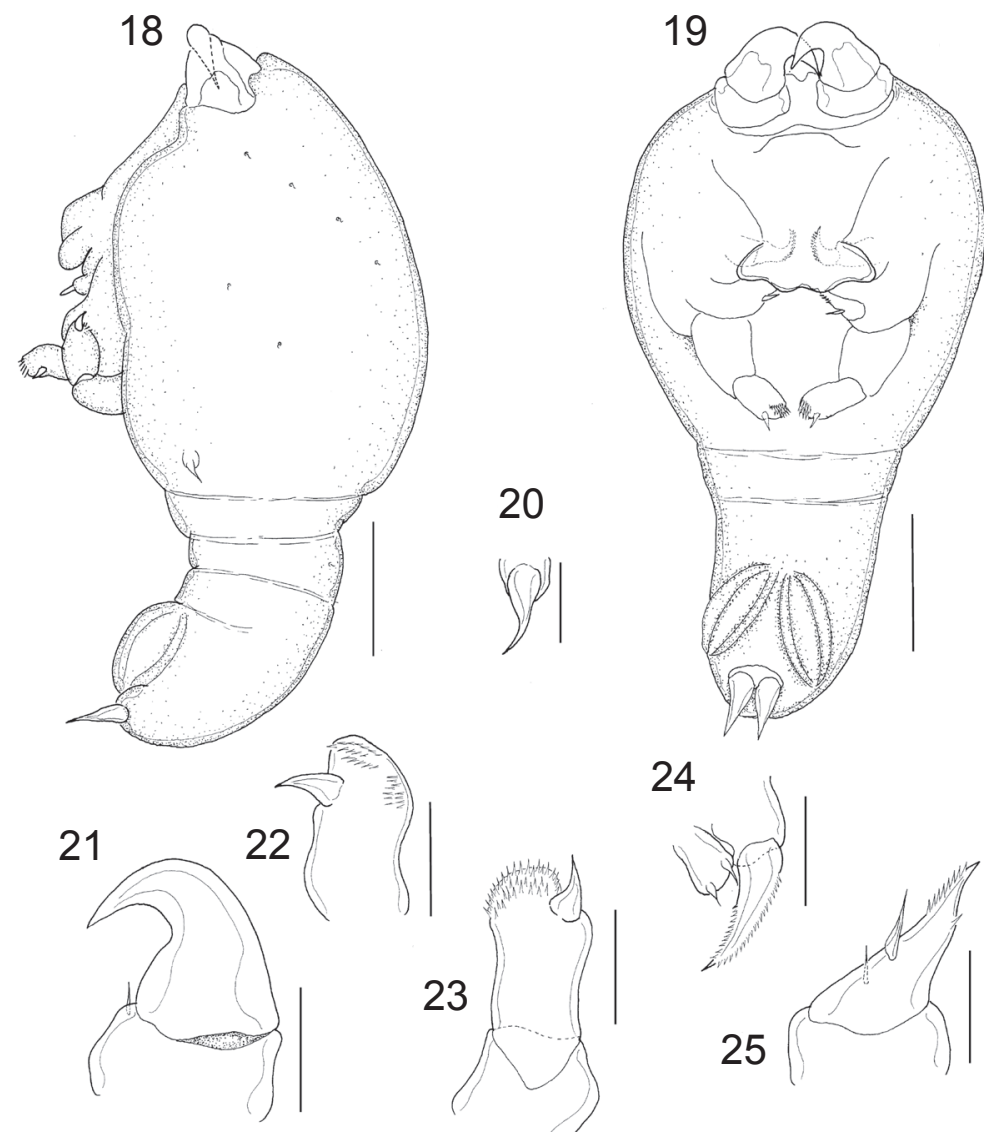

24
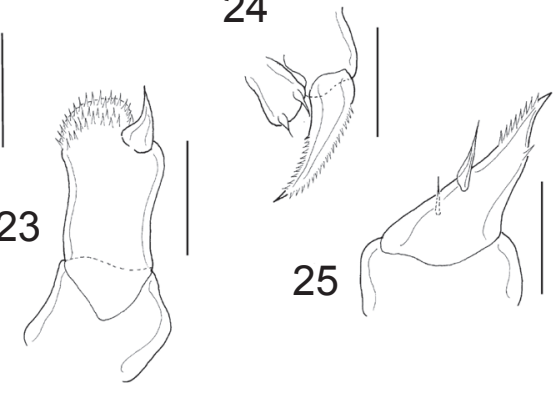

Figs. 18-25. Heterochondria orientalis sp. n., male. Fig. 18. Habitus, lateral view. Fig. 19. Habitus, ventral view. Fig. 20. Leg 1. Fig. 21. Antenna. Figs. 22, 23. Maxilliped. Fig. 24. Mandible and maxillule. Fig. 25. Maxilla. Scale bars: Figs. 18, $19=70 \mu \mathrm{m}$; Figs. 20 , $22-25=10 \mu \mathrm{m}$; Fig. $21=20 \mu \mathrm{m}$.

Mandible (Fig. 24) with fewer teeth on terminal blade, 18 and 11 teeth on convex and concave sides, respectively. Maxillule (Fig. 24) same as in female. Maxilla (Fig. 25) with eight teeth on inner side and one on outerside of terminal process. Maxilliped (Figs. 22, 23) essentially as in female, but terminal claw relatively larger. Leg 1 (Fig. 20) reduced to simple spiniform seta. Leg 2 absent.

Type host: Zebrias fasciatus (Basilewsky) (Pleuronectiformes, Soleidae).

Type locality: Off Yeosu $\left(34^{\circ} 41^{\prime} \mathrm{N}, 127^{\circ} 49^{\prime} \mathrm{E}\right)$, Korea.

Site of infections: Gill rakers and inner side of operculum.

Prevalence: $17 \%$ (2 fish infected out of 12 examined).

Mean intensity: 4.

Material deposited: Holotype female (NIBRIV0000266713), allotype male (NIBRIV0000266717), and two paratypes, paratype female (NIBRIV0000266714) dissected and mounted one glass slide and egg sac in vial, paratymale (NIBRIV0000266715) undissected and mounted on one glass slide are deposited in the NIBR, off Yeosu, Korea, 24 September 2012.

Other materials: four paratypes (two non-ovigerous females each with one attached male) (NIBRIV NIBRIV0000266716) from the Yellow Sea $\left(36^{\circ} 40^{\prime} \mathrm{N}\right.$, $\left.126^{\circ} 04^{\prime} \mathrm{E}\right)$, Korea, 15 May 2010 . All specimens collected by the first author.

Variability: Non-ovigerous female (Figs. 8, 9) 2.61-3.17 $\mathrm{mm}$ long, with more slender trunk than ovigerous female.

E t y m o log y: The specific name orientalis refers to the locality of the new species from East (= oriental) Asia.

Remarks. The species of Heterochondria can be separated into two groups according to the presence or absence of nipple-like bud on the medial surface of leg 1 in females. Females of $H$. orientalis sp. $\mathrm{n}$ share the nipplelike bud on the female leg 1 with two congeners: $H$. pillai Ho, 1970 and H. zebriae Ho, Kim et Kumar, 2000 (Ho et al. 2000). The new species can be differentiated from these two morphologically similar species as follows.

Based on female specimens, $H$. orientalis sp. n. differs from $H$. pillai by a pair of posterolateral processes (vs without in $H$. pillai); bottle-shaped body dorsally ( $v s$ elongated and cylindrical in $H$. pillai); head 1.26 times longer than wide (vs 1.88 times longer than wide in H. pillai); more teeth on the convex side of the mandible (vs less in H. pillai); and fewer teeth on the terminal process of the maxilla ( $v s$ more in H. pillai). In the males: the antennule absent ( $v s$ reduced to a small rod tipped with 
Table 1. Species of Heterochondria (Chondracanthidae), their hosts and geographical distribution.

\begin{tabular}{|c|c|c|c|c|}
\hline Copepods & Host families & Host species & $\begin{array}{l}\text { Geographical } \\
\text { localities }\end{array}$ & References \\
\hline H. atypica Ho, 1972 & Labridae & Oxyjulis californica (Günther) & California, USA & Нo (1972) \\
\hline \multirow[t]{2}{*}{ H. crassicornis (Krøyer, 1837) } & Labridae & Labrus sp. & India & Krøyer (1837) \\
\hline & Pomacentridae & $\begin{array}{l}\text { Pomacentrus planifrons Cuvier } \\
\text { (= Stegastes planifrons) }\end{array}$ & $\begin{array}{l}\text { Dry Tortugas } \\
\text { Island, USA }\end{array}$ & Wilson (1935) \\
\hline \multirow[t]{3}{*}{ H. cynoglottidis (Thompson et Scott, 1903) } & Cynoglossidae & Cynoglossus kopsii (Bleeker) & Sri Lanka & Kirtisinghe (1964) \\
\hline & Cynoglossidae & $\begin{array}{l}\text { Cynoglossus puncticeps } \\
\text { (Richardson) }\end{array}$ & Sri Lanka & $\begin{array}{l}\text { Thompson and } \\
\text { Scott (1903) }\end{array}$ \\
\hline & Cynoglossidae & Cynoglossus semifasciatus Day & Sri Lanka & $\begin{array}{l}\text { Thompson and } \\
\text { Scott (1903) }\end{array}$ \\
\hline \multirow[t]{2}{*}{ H. longa Tripathi, 1961} & Paralichthyidae & Pseudorhombus arsius (Hamilton) & India & Tripathi (1960) \\
\hline & Paralichthyidae & $\begin{array}{l}\text { Pseudorhombus triocellatus } \\
\text { (Bloch et Schneider) }\end{array}$ & India & Tripathi (1960) \\
\hline \multirow[t]{3}{*}{ H. longicephala (Yü et Wu, 1932) } & Paralichthyidae & Pseudorhombus arsius (Hamilton) & South China Sea & Yü and Wu (1932) \\
\hline & Paralichthyidae & Pseudorhombus neglectus Bleeker & Taiwan & Ho et al. (2011) \\
\hline & Paralichthyidae & $\begin{array}{l}\text { Pseudorhombus oligodon } \\
\text { (Bleeker) }\end{array}$ & Taiwan & Ho et al. (2011) \\
\hline H. orientalis sp. $\mathrm{n}$. & Soleidae & Zebrias fasciatus (Basilewsky) & Korea & Present study \\
\hline \multirow[t]{3}{*}{ H. petila Ho, Kim et Kumar, 2000} & Paralichthyidae & Pseudorhombus arsius (Hamilton) & India & Ho et al. (2000) \\
\hline & Paralichthyidae & $\begin{array}{l}\text { Pseudorhombus javanicus } \\
\text { (Bleeker) }\end{array}$ & India & Ho et al. (2000) \\
\hline & Paralichthyidae & $\begin{array}{l}\text { Pseudorhombus triocellatus } \\
\text { (Bloch and Schneider) }\end{array}$ & India & Ho et al. (2000) \\
\hline \multirow[t]{7}{*}{ H. pillaii Ho, 1970} & Paralichthyidae & Pseudorhombus arsius (Hamilton) & India & Ho (1970) \\
\hline & Cynoglossidae & Cynoglossus dubius Day & India & Ho et al. (2000) \\
\hline & Cynoglossidae & Cynoglossus lida (Bleeker) & India & Ho et al. (2000) \\
\hline & Paralichthyidae & Pseudorhombus arsius (Hamilton) & India & Pillai (1985) \\
\hline & Paralichthyidae & Pseudorhombus elevates Ogilby & India & Ho et al. (2000) \\
\hline & Paralichthyidae & $\begin{array}{l}\text { Pseudorhombus javanicus } \\
\text { (Bleeker) }\end{array}$ & India & Ho et al. (2000) \\
\hline & Paralichthyidae & $\begin{array}{l}\text { Pseudorhombus triocellatus } \\
\text { (Bloch et Schneider) }\end{array}$ & India & Ho et al. (2000) \\
\hline \multirow[t]{2}{*}{ H. similis (Yü et $\mathrm{Wu}, 1932$ ) } & Bothidae & Crossorhombus azureus (Alcock) & South China Sea & Yü and Wu (1932) \\
\hline & Bothidae & Crossorhombus azureus (Alcock) & India & Ho et al. (2000) \\
\hline H. zebriae (Ho, Kim et Kumar, 2000) & Soleidae & Zebrias synapturoides (Jenkins) & India & Ho et al. (2000) \\
\hline
\end{tabular}

few setae in $H$. pillai); more teeth on the convex and concave sides (vs less in $H$. pillai); and more on the terminal process of the maxilla ( $v s$ less in $H$. pillai).

The new species is closely related to $H$. zebriae, but can be distinguished from the latter based on the both sexes: the median trunk ratio of $3.13: 1$ (length/width) in $H$. orientalis (vs 4.62:1 in H. zebriae); smaller antenna (vs larger in H. zebriae); the terminal segment with sharply curved claw with striation in the subterminal region ( $v s$ absent in $H$. zebriae); more teeth on the convex side of the mandible ( $v s$ less in H. zebriae); less teeth on the terminal process of the maxilla ( $v s$ more in H. zebriae); antennule absent in male ( $v s$ reduced to a simple seta in H. zebriae); and more spinules on the inner-distal corner at the second segment of the maxilliped in the male (vs less in H. zebriae).

\section{DISCUSSION}

The genus Heterochondria shows some similarities in its morphological characteristics with Acanthochondria and Chondracanthus, but differs in the following combination of characteristics present in the both sexes (see Ho 1970, Ho et al. 2000, 2011, Boxshall and Halsey 2004): presence or absence of a nipple-like bud on the medial surface of legs 1 and 2 in females; presence or absence of antennule in males; leg 1 reduced to a spiniform seta or minute setae; and leg 2 absent in males.

Females of Heterochondria orientalis have a relatively elongated exopod and a reduced nipple-like endopod on legs 1 and 2, similarly as females of $H$. zebriae and H. pillaii-Ho (1970), Ho et al. (2000), Tang et al. (2010). Based on the present study, the following characteristics are considered to be useful for species identification. Females: proportion and shape of the body; length/width ratio of the trunk; proportion and structure of the head; presence/absence of the posterolateral process on the trunk; fine structure of oral appendages; shape of the terminal claw of the maxilliped; and the presence/absence of a reduced nipple-like endopod on legs 1 and 2. Males: the antennule absence or present; fine structure of oral appendages; and structure and general appearance of legs 1 and 2.

Currently, Heterochondria consists of ten nominal species (Boxshall and Halsey 2004, Ho et al. 2000, 2011), including the new one described herein. Nine species are reported from Asia, whereas two from North America (see Table 1). All species of Heterochondria have been reported from fish hosts of six different families (see Table 1), 
with the dominant family being the Paralichthyidae, the species of which serve as hosts for four species (Table 1). Species of the three remaining fish families serve as hosts for one or two species each (see Table 1).

Heterochondria zebriae was originally described by Ho et al. (2000) based on 24 adult and three juvenile females plus 19 adult males collected from the gill filaments of the Indian zebra sole, Zebrias synapturoides (Jenkins), caught off the coast of Kerala, India. This host is distributed widely throughout the Indo-Pacific (Froese and Pauly 2012).

The new species parasitizes Z. faciatus, which occurs mainly in the Northwest Pacific (Yellow, Bohai and East China Seas) (Froese and Pauly 2012). This indicates that species of Heterochondria may be distributed extensively in the Indo-Pacific region, including the Northwest $\mathrm{Pa}$ cific. However, the testing of this hypothesis awaits more detailed knowledge on host-specificity and zoogeography of species of Heterochondria.

To facilitate identification of all ten nominal species of the genus (see Table 1 for their list), a simple key based on morphology of adult females is provided.

\section{Key to the species of Heterochondria (adult females)}

1 Terminal claw of maxilliped with bifurcate tip H. longa Tripathi, 1961

- Terminal claw of maxilliped without bifurcate tip .. 2

2 Trunk with a pair of posterolateral processes ......... 3

- Trunk without a pair of posterolateral processes ..... 4

3 Trunk more than $4 \times$ longer than wide; antenna large and sharply curved without striation in subterminal region ........... H. zebriae (Ho, Kim et Kumar, 2000)

- Trunk less than $4 \times$ longer than wide; antenna large and sharply curved with striation in subterminal region

H. orientalis sp. $\mathrm{n}$.

4 Legs 1 and 2 with a reduced nipple-like endopod ...... H. pillai Ho, 1970
- Legs 1 and 2 without a reduced nipple-like endopod ..

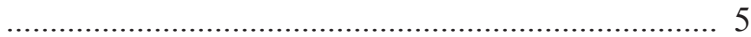

5 Head wider than widest part of trunk; trunk cylindrical ......... H. cynoglottidis (Thompson et Scott, 1903)

- Head narrower than widest part of trunk; trunk cylindrical ...................................................................... 6

- Head narrower than widest part of trunk; trunk not cylindrical 8

6 Trunk approximately $6 \times$ longer than wide; row of denticles on each side of shaft of terminal claw of maxilliped absent ......... H. petila Ho, Kim et Kumar, 2000

- Trunk less than $6 \times$ longer than wide; row of denticles on each side of shaft of terminal claw of maxilliped present 7

7 Head with prominent knob on anterolateral corner; terminal pointed process of maxilliped with row of teeth on convex and concave sides

H. atypica Ho, 1972

- Head without prominent knob on anterolateral corner; terminal pointed process of maxilliped with row of teeth on convex side only

H. crassicornis (Krøyer, 1837)

8 Terminal process of mandible with 19-22 teeth on concave side and 51-54 teeth on convex side

H. longicephala (Yü et $\mathrm{Wu}, 1932$ )

- Terminal process of mandible with less than 15 teeth on concave side and 45 teeth on convex side H. similis (Yü et Wu, 1932)

Acknowledgements. Thanks are due to Dr. B.A. Venmathi Maran, Korean Institute of Ocean Science \& Technology (KIOST), for reading an early draft of this manuscript. This research was supported by the National Research Foundation of Korea Grant funded by the Korean Government (NRF-351-2009-1-C00060), and the project 'The Discovery of Korean Indigenous Species' supported by the National Institute of Biological Resources (NIBR), Korea.

\section{REFERENCES}

Alacros A.J., Timi J.T. 2011: A new species of Acanthochondria (Copepoda: Chondracanthidae) parasitizing the flounder Xystreurys rasile (Pleuronectiformes: Paralichthyidae) from Argentina. Folia Parasitol. 58: 164-168.

Boxhall G.A., Halsey S.H. 2004: An Introduction to Copepod Diversity. The Ray Society, London, 966 pp.

Braicovich P.E., Timi J.T. 2009: Acanthochondria serrani sp. n. (Copepoda: Chondracanthidae) parasitic on Serranus auriga (Perciformes: Serranidae) from Argentinean waters. Folia Parasitol. 56: 313-316.

Cantatore D.M.P., Lanfrenchi A.L., Timi J.T. 2011: New species of Acanthochondria (Copepoda: Chondracanthidae) infecting the longtail southern cod, Patagonotothen ramsary
(Perciformes: Nototheniidae), from Patagonian waters, Argentina. J. Parasitol. 97: 1007-1011.

Froese R., Pauly D. (Eds.) 2012: FishBase. World Wide Web electronic publication, www.fishbase.or, 12/2012.

Ho J.S. 1970: Revision of the genera of the Chondracanthidae, a copepod family parasitic on marine fishes. Beaufortia 17: $105-218$.

Ho J.S. 1972: Four new parasitic copepod of the family Chondracanthidae from California inshore fishes. Proc. Biol. Soc. Wash. 85: 523-539.

Ho J.S. 1982: On the origin of Chondracanthidae, a family of Copepoda parasitic on marine fish. Wiad. Parazytol. 28: 191195. 
Ho J.S., Kim I.H., Kumar A.B. 2000: Chondracanthid copepods parasitic on flatfishes of Kerala, India. J. Nat. Hist. 34: 709-735.

Ho J.S., Lin C.L., Lin W.C. 2011: Chondracanthid copepods parasitic on flatfishes of Taiwan. Crustaceana 84: 331-373.

Humes A.G., Gooding R.U. 1964: A method for studying the external anatomy of copepods. Crustaceana 6: 238-240.

KIm I.H. 1998: Cirripedia, Symbiotic Copepoda, and Pycnogonida. [Illustrated Encyclopedia of Fauna and Flora of Korea.] Vol. 38. Ministry of Education, Seoul, 1038 pp. (In Korean.)

Kim I.S., Choi Y., Lee C.L., Lee Y.J., Kim B.J., Kim J.H. 2005: [Illustrated Book of Korean Fishes.] Kyohak Publ. Seoul, 613 pp. (In Korean.)

Kirtisinghe P. 1964: A review of the parasitic copepods of fish recorded from Ceylon with description of additional forms. Bull. Fish. Res. Stat. Ceylon 17: 45-132.

Krøyer H. 1837: Om snylterkrebsene, isaer med hensyn til den Danske Fauna. Naturh. Tidsskr. 1: 172-208.

Østergaard P. 2003: Catalogue of genera and species of the family Chondracanthidae Milne Edwards, 1840 (Copepoda: Poecilostomatoida) with notes on morphology. Syst. Parasitol. 55: $135-150$.

Received 7 January 2013
Pillai N.K. 1985: The Fauna of India. Copepod Parasites of Marine Fishes. Zoological Society of India, Calcutta. 900 pp.

Tang D., Kalman J.E., Ho J.S. 2010: Acanthochondria cyclopsetta Pearse, 1952 and A. alleni sp. n. (Copepoda; Cyclopoida; Chondracanthidae) from flatfish hosts of the U.S.A., with comments on the taxonomic position of $A$. zebriae Ho, Kim et Kumar, 2000 and $A$. bicornis Shiino, 1955 and the validity of Pterochondria Ho, 1973. Zootaxa 2657: 18-32.

Thompson G.M., Scott A. 1903: On the Copepoda collected by Professor Herdman, at Ceylon, in 1902. Ceylon Pearl Oyster Fish. 1 (suppl. Reps. 7): 227-307.

TRIPAThi Y.R. 1960: Parasitic copepods from Indian fishes. I. Family Chondracanthidae Milne Edwards, 1840. J. Zool. Soc. India 12: 51-59.

Uyeno D., Nagasawa K. 2012: Ttetaloia hoshinoi, a new genus and species of chondracanthid copepod (Poecilostomatoida) parasitic on triplefins (Actinopterygii: Tripterygiidae) from Japanese waters. Zoosymposia 8: 39-48.

Wilson C.B. 1935: Parasitic copepods from the Pacific coast. Am. Midl. Nat. 16: 776-797.

YÜ S.C., WU H.W. 1932: Parasitic copepods of the flat-fishes from China. Bull. Fan Mem. Inst. Biol. 3: 55-75.

Accepted 24 February 2013 